\title{
Stock Market Liquidity Measurement via the Bid-Ask Spread: Tunis Stockmarket
}

\author{
Hsini Mosbeh (corresponding author) \\ Higher Institute of Commerce and Accountancy of Bizerte, Carthage University, Tunisia \\ Email: lahsinim@gmail.com
}

Mohamed Nidhal MOSBAHI

Higher Institute of Commerce and Accountancy of Bizerte, Carthage University, Tunisia

Email: mosbahinidhal@ hotmail.com

Received: May 6, 2016 Accepted: May 22, 2016

doi:10.5296/ber.v6i2.9753 URL: http://dx.doi.org/10.5296/ber.v6i2.9753

\begin{abstract}
In this paper, we attempt to explore the nature of the linkage relation of liquidity with market structure. Owing to his function of serving liquidity immediacy, the market maker determines his transacting prices (bid and ask) with all other operators. Accordingly, via his bid-ask spread, he does orient the transaction flow. This study shuts for testing a measure of market liquidity via the bid-ask spread via Stoll Model methodology (1989) on the covariance s' regressions on Tunis stock market over a period stretching from January 2005 until January 2012. The results show that the higher the spread; the less liquid is the market.
\end{abstract}

Keywords: Liquidity, Market maker, Bid-ask spread, Stock prices.

JEL Classification: C22, D 82, G11, G12

\section{Introduction}

Microstructure theory of financial markets has tried to advance some answers to three basic questions about the interaction between different market participants, trade mechanisms, and the dynamics of financial assets' prices. It inquires about the way the market maker operates when determining his spread; and also how financial market liquidity is measured? Hence, interest is growing for more than two decades dealing with financial markets microstructure and reflects stock market authorities' determination to find the most appropriate structure to 
minimize transaction costs and especially increase market liquidity. Therefore, this work aims to emphasize the extent of market liquidity measure. It postulates that the gap between transaction price of a financial asset and its intrinsic value is fundamentally linked to transaction costs, which are of two types: direct costs involving market access and information costs; and indirect or implicit costs (the spread). In fact, the acquisition of a financial asset generally poses a problem of determining the value at which it must be exchanged. Therefore, the price formation process is usually correlated with the exchange modality diversity and especially with the analysis of the spread determinants between the bid and ask prices.

\section{Theorical Models of Spread}

Demsetz (1968) provided the first formal study of the spread in a market governed by prices. He put the stress on the fact that the essential function of a market maker is to ensure market liquidity by offsetting the temporary imbalances between supply and demand through purchases or sales on its own stock of assets. Thus, the intermediate (the specialist) is ready to satisfy either a purchase order as it arrives (by selling for his own account) or a sale order as it arrives (by buying for its own account). In exchange for this immediacy service and the risk he undergoes when binding himself to satisfy on its own account any supply or demand that is expressed on the market. He asks in counterpart a cost (a remuneration) since he provides investors wanting to sell a financial asset, a slightly lower price than it would have had on an auction market. This first price is the price at which the market maker satisfied sellers. This is known as the bid price. The second price is the price at which he satisfied buyers. This is known as the ask price. The difference between these two prices shapes the price range or the bid-ask spread. Thus, it is appropriate to introduce two categories of models dealing with the intermediaries' behavior in financial markets. On the one hand, the inventory or the position paradigm assuming that the market maker must take potentially excessive risk positions to satisfy the public's liquidity needs. On the other hands, the information paradigm analyzes the adverse selection problem the market maker faces [Glosten and Milgrom (1985), Easley and O’Hara (1987), Shiller (1999), Brokman and Chung (2000), Hirschey (2001)].

\subsection{The Inventory Theory (Position Paradigm)}

Mainly developed by Stoll (1978), Ho and Stoll (1983), Bikhchandani et al. (1992), and Biais (1993), the basic intuition of the position paradigm is that a market maker, owing his function of supplying immediacy, should have positions on each of the financial assets he processes and strives to avoid taking too important positions (with purchase (long positions) or sale (short position)) [Hu et al.(2013), Ai (2010)]. Thus, the market maker has the prices as a recovery means of his situation. And then, by varying his buying and selling prices, he can favorably orientate the order flow. In this sense, this specialist can encourage or discourage the trading in one direction or another, according to his preferences. A "short" intermediate, the one who sold too and has a negative equity stock, is well aware that an additional public purchase would increase his exposure. The concern to temper this state does push him to set higher both selling and purchase prices. In this regard, he will discourage investors willing to 
buy and do encourage those who want to sell. After a certain time and a certain number of transactions, the market maker will restore consequently his expected position. In contrast, an intermediate having an excessive inventory regarding to what he wants, resorts to a reverse strategy by reducing both his bid price (when buying) and ask price (sale). This will accordingly decrease the likelihood of receiving a sale order and increase that of receiving a purchase order. Biais (1993) states that setting his purchase and sale prices, allows the market maker to control optimally his position. Thus, the two prices therefore depend on the position of the intermediary and thus reflect his personal preferences.

\subsection{The Asymmetric Information Theory (Information Paradigm)}

This paradigm developed mainly by Copeland and Galai (1983), Glosten and Milgrom (1985), Easley and O'Hara (1992), refers abusively to efficient market theory. The starting point of information asymmetry is market inefficiency. Furthermore, access to information is neither free nor instantaneous for all participants and also the disparity of investors regarding access to information where there are the insiders having private information, and uninformed (outsiders or liquidity traders) having only public information available to all operators in presence of a risk neutral market maker. In fact, the presence of agents with private information poses to this intermediate an adverse selection problem. Thus, owing to his inability to discern investors motivated by liquidity from those motivated by information, the market maker stands, before doing any transaction, forced to include into his prices a cost that would offset the potential losses when facing informed investors [Roll (1984), Kyle (1985)]. Therefore, the intermediate concern focuses around his intention to lose on transactions with insiders and to win by transacting with liquidity traders. This phenomenon is conveyed by the fact that insiders do not buy (from the intermediate) only if they anticipate that the "real" price of such an asset is greater than the ask price of the intermediate (true price $>$ bid price) and they do not sell only if the real price is lower than the bid price of the intermediate (true price < ask price). In contrast, the market maker can make a profit by transacting with liquidity traders insofar as he receives the spread between his bid and ask prices. In order to temper the puzzle of the market maker adverse selection (he cannot distinguish if he transacted with an uninformed or an informed agent), this market maker is accordingly obliged to set a sufficiently wide spread (wide) for that on average, the losses emanating from insiders be offset by gains on uninformed investors (outsiders) who transact for hedging reason or liquidity needs [Shiller (1999), Chordia and Swaminathan (2000)]. It is true that the intermediary can take advantage from his transactions with liquidity traders, however, this can upside discourage these investors to undertake transactions since the spread (transaction costs they incur) became quite wide, thereby reducing the transactions volume. The market maker ability to expand the spread is limited by the fact that the request to his service has a negative slope. In short, the price range (spread) formation is modeled via two basic approaches (two paradigms):

* The inventory cost models that consider the range as a risk remuneration induced by the asset stock since the stock accumulation leaves his portfolio non-diversified.

* The information asymmetry models that assume the range as a compensation for potential 
losses that the market maker can undergo face better informed traders than him [Roll (1984), Biais et al. (1995), Chordia and Swaminathan (2000), Admati and Pfleiderer (1988), Shiller (1989), Ziegler (2001)]. It is significant to consider these two theories of inventory and information are interested in different aspects of market maker behavior.

\section{Financial Market Liquidity}

\subsection{Liquidity Theory}

Garman (1976) states that a liquid market is a market where an agent can quickly perform significant transactions without causing significant price variation. Indeed, two conditions must be met for a market to be liquid:

* There must be an offer (respectively, a demand) large enough for a buyer (seller) can complete a transaction without causing a sharp increase (decrease) in prices. Sometimes the occurrence of certain price variations is due to temporary imbalances between supply and demand but that must be quickly adjusted.

* Within a liquid market, an operator has to be able to quickly find a counterpart. Thus, when he submits an order where its execution is not immediate, he runs the risk that new information arrival does change the asset intrinsic (fundamental) value before his order has been executed. Accordingly, the quicker an order execution, the more limited this risk [Jennings (1998), Lee et al. (1999), Shiller (1999), Hirschey (200 1), Foucault (1999)]. Therefore, once these conditions are unmet, a buyer has to pay a price higher than the fundamental value and likely a seller in turn receives inferior lower price. This difference between the transaction price and the fundamental value of an asset corresponds to the cost of market illiquidity for both buyers and sellers. In the same vein, the more liquid a market is, the more the orders implementation costs are reduced. Thus, market liquidity is desirable in the sense that it weakens the returns required by investors since liquidity has an inverse significant impact on returns. Then, once liquidity increases, return declines and vice versa [Amihud and Mendelson (1986), Karpoff (1986), Hailer and Stoll (1989), Stoll (1989), Grossman and Miller (1989), Leland (1982)]. They stipulate that average returns are even lower than the spread is too low and consequently liquidity increases. Biais et al. (1995) postulate a financial asset is liquid if it is possible to buy or sell it quickly, supporting moderate cost transactions, with an affordable price. Indeed, the more important is the volume of transactions, the easier is to transact quickly. Regarding the liquidity relationship with the market structure, many studies have largely put the stress on the fact that the market structure affects the liquidity of securities treated within. Besides, if the market is very transparent and also if the information is quickly and efficiently broadcast, the participants in this market will have rapidly knowledge of the orders transmission, which will facilitate the transactions achievement. Briefly, liquidity appears reflecting the market ability to absorb large volume of securities' transactions without causing prices varying significantly [Chordia and Swaminathan (2000), Easley and O' Hara (2010)]. It may be a counterparty or agency market, or a centralized or fragmented market, a continuous or fixing market, it should be noted that in all these market structures, liquidity comes from the prices quoted by some agents, mainly the market maker in a counterparty market (governed price market) or the 
ultimate investors in a governed order market. Thus, the better the liquidity of a market, the greater operational efficiency. Nevertheless, liquidity is satisfying only if the price should accurately reflect the supply and demand of such an asset.

\subsection{The Liquidity Measurement}

Numerous studies and investigations have been developed to measure market liquidity. The objective of these studies is to provide theoretical and empirical analysis that fit into contributions to reduce the ambiguity of the liquidity concept. The main types of liquidity measure are the following ones:

* The Market Efficiency Coefficient (MEC) developed by Hasbrouk (1998) is calculated from the transaction price.

$$
\operatorname{MEC}=\operatorname{Var}\left(\mathrm{R}_{\mathrm{T}}\right) / \mathrm{T} x \operatorname{Var}\left(\mathrm{R}_{\mathrm{t}}\right)
$$

$\operatorname{Var}(\mathrm{RT})$ and $\operatorname{Var}\left(\mathrm{R}_{\mathrm{t}}\right)$ are the returns' variances measured at intervals of length $\mathrm{T}$ and $\mathrm{t}$, respectively.

$\mathbf{T}$ is the ratio of the length of the longest interval over the length of the shortest interval. The basic idea is that in an efficient market, the returns' variance measured over intervals of different length is proportional to the length of the interval. We note in this context that the hypothetical (assumed) variance of returns measured over long intervals $\operatorname{Var}\left(\mathrm{R}_{\mathrm{T}}\right)$ has some returns that are induced by information; while those of returns measured over short intervals $\operatorname{Var}\left(\mathrm{R}_{\mathrm{t}}\right)$ are affected by price movements induced by liquidity. So, the short interval is measured from the opening to close or vice versa, while the long one is measured from the opening to opening session.

* The total variability of returns introduced by Amihud and Mendelson (1987) as a measure of financial market liquidity and states that returns' variance necessarily contains price movements induced both by information and liquidity. This variance of returns is thus calculated from the opening and closing prices. The total variability of returns is thus the ratio between the variance of opening-opening and the variance of closing -closing returns. Many empirical studies show that this ratio is greater than one.

* Securities' rotation: This ratio corresponds to the number of shares traded divided by the number of outstanding (in circulation) shares. Therefore, the higher this ratio, the more liquid the market.

* The price range or the bid-ask spread seems as the most common and the most important measure of market liquidity. In fact, liquidity can be measured via two methods: either directly from quoted prices (displayed spread), or indirectly from the transaction price (achieved spread).

\section{Liquidity Measurement: An Empirical Study}

The spread theory has evolved continuously since Demsetz (1968) and is still today the central axis of market microstructure theory. Developed in particular by Chordia and Swaminathan (2000) the spread traduces the gap between the best bid price and the best ask 
price on a governed price market. The spread is known as "the most widespread measure of liquidity". Hence we will pay later paramount consideration to the spread study at this following empirical investigation.

\subsection{Dynamics Bid-Ask Spread}

\subsubsection{Spread Determinants}

The spread displayed by the market maker is, at a given time, equal to the gap between the price he is willing to sell and the one to which he commits to purchase. The first price is higher than the second and then the difference corresponds to remuneration for the provided service. Consequently, the spread represents an implicit cost since the return of a purchased sold is encumbered by gap between the bid and the ask price. However, if the displayed spread differs from that achieved, it is that the latter which constitutes the implicit transaction cost (the achieved spread does not coincide with the one initially displayed). The main purpose of this research is to estimate the percentage that the achieved spread represents compared to that displayed. A first approach modeling this achieved spread and provides a measurement related to observed correlations of prices' variations is Roll model (1984) that explained the existence of autocorrelation between the transaction prices' returns via the spread. Roll considered that this range is composed only by the order processing costs. Thus, the estimated spread can be derived from the serial covariance of successive price changes.

$$
(\Delta \mathrm{Pt}, \Delta \mathrm{Pt}+1)=-\mathrm{S} 2 / 4
$$

Indeed, recent literature implies that the displayed spread is not translated only by the order processing costs but through three kinds of costs simultaneously: order processing costs, the inventory holding costs and the adverse information costs. The Roll (1984)'s model was generalized particularly by Stoll (1989) who identified three spread components and infers the achieved spread from observed autocorrelations not only in securities' prices but also the best limits (bid or ask) [Biais et al. (1995), Shiller (1999)

\subsubsection{Transaction and Spread Evolution in Each of These Three Theories}

At a time $\mathrm{t}=0$, the ask and bid prices are $\mathrm{P}_{0}{ }^{\mathrm{a}}$ and $\mathrm{P}_{0}{ }^{\mathrm{b}}$ respectively, then the displayed spread ( $\mathrm{t}$ $=0$ ) is $S_{0}=P_{0}{ }^{a}-P_{0}{ }^{b}$. This spread actually depends on the transactions' size that differs from one transaction to another. Suppose the case of a transaction that takes place at $\mathrm{P}_{0}{ }^{\mathrm{b}}$ and examine later at time $\mathrm{t}=1$, how the new bid and ask $\mathrm{P}_{1}{ }^{\mathrm{b}}$ and $\mathrm{P}_{1}{ }^{\mathrm{a}}$ will be established under the various models of the spread, while assuming that no new information other than that conveyed by the transaction itself, reaches the market, and the spread $\mathrm{S}$ is constant.

The model of order execution costs when the spread reflects only the order execution costs, quotations $\mathrm{P}^{\mathrm{a}}$ and $\mathrm{P}^{\mathrm{b}}$ always do center the intrinsic value of the security, resulting at new bid and ask prices $\mathrm{P}_{1}{ }^{\mathrm{b}}$ and $\mathrm{P}_{1}{ }^{\mathrm{a}}$ which are none other than the former i.e. $\mathrm{P}_{0}{ }^{\mathrm{b}}$ et $\mathrm{P}_{0}{ }^{\mathrm{a}}$. Assuming that a transaction occurs in $\mathrm{P}_{0}{ }^{\mathrm{a}}$ (market maker purchase), the achieved spread $\mathrm{P}_{1}{ }^{\mathrm{b}}-\mathrm{P}_{0}{ }^{\mathrm{a}}$ is the same as the quoted spread $\mathrm{P}_{0}{ }^{\mathrm{a}}-\mathrm{P}_{0}{ }^{\mathrm{b}}=\mathrm{S}$. Similarly, assuming that a transaction occurs at $\mathrm{P}_{0}{ }^{\mathrm{a}}$ (public sale). Under the same conditions, we have: $\mathrm{S}=\mathrm{P}_{0}{ }^{\mathrm{a}}-\mathrm{P}_{1}{ }^{\mathrm{b}}=\mathrm{P}_{0}{ }^{\mathrm{a}}-\mathrm{P}_{0}{ }^{\mathrm{b}}$

Model of Inventory Control Costs To assume that inventory costs are linear with respect to 
the portfolio and symmetrical with respect to transactions, means that price changes are symmetrical. More specifically, the bid and ask prices will fall by $0.5 \mathrm{~S}$ after a Market Maker purchase and raise $0.5 \mathrm{~S}$ after a sale from him. This variation of $0.5 \mathrm{~S}$ comes from the fact that the market maker is willing to buy as well as to sell. Thus, the spread $\mathrm{P}^{\mathrm{a}}-\mathrm{P}^{\mathrm{b}}$ is twice the inventory cost of a transaction. The spread that the intermediate achieves if he sells after a buying is $\mathrm{P}_{0}{ }^{\mathrm{a}}-\mathrm{P}_{0}{ }^{\mathrm{b}}$ which is only $0.5 \mathrm{~S}$ ( $\mathrm{S}$ : displayed Spread).

* Model of asymmetric information costs In this case, the bid and ask prices vary in the same way as the adjustment model (inventory), but for a different reason. So, after a market maker purchase from public, bid and ask will go down since a transaction at $\mathrm{P}_{0}{ }^{\mathrm{b}}$ conveys information that the anticipated equilibrium price is lower. The expected equilibrium price at $\mathrm{t}=0$ is then $\left(\mathrm{P}_{0}{ }^{\mathrm{a}}+\mathrm{P}_{0}{ }^{\mathrm{b}}\right) / 2$. Similarly, a market maker sale conveys information prompting the latter to revise the expected equilibrium price down and to fix it at $\left(\mathrm{P}_{1}{ }^{\mathrm{a}}+\mathrm{P}_{1}{ }^{\mathrm{b}}\right) / 2$. Thus, in both cases, the achieved spread is necessarily less than that quoted by the intermediate. Indeed, the three spread approaches can be summarized by the value of two parameters, $\partial$ and $\Pi$ as shown in the table below. $\Pi$ is the probability of a reversal in prices, i.e. the likelihood that a transaction at ask price (bid) is followed by a transaction at bid price (ask); (1-П) is the likelihood of prices' continuation. $\partial$ is the variation fraction (increase or decrease) of the quoted spread when there is a price continuation; and (1- $\partial$ ) is the variation fraction of the quoted spread when there is a price reversal. Thus, under the assumption of a constant spread, a price reversal occurs with probability $\Pi$ and with a size of $(1-\partial) * S$, where $S$ is the spread and $0<\partial<1$. In contrast, a price continuation has a probability (1- П) to occur, and with a size of $\partial . S$. In short, the parameters $\Pi$ and $\partial$ can be summarized as follows.

Table 1. The spread component costs

\begin{tabular}{|c|c|c|}
\hline Spread Determinants & $\partial$ & $\Pi$ \\
\hline Processing costs & 0 & 0.5 \\
\hline Inventory Control Costs & 0.5 & $0.5<\prod<1$ \\
\hline asymmetric information costs & 0.5 & 0.5 \\
\hline
\end{tabular}

Stoll (1999) modelizes prices moving (displacement) using the spread $S$ and the parameters $\Pi$ (boundary change probability) and $\partial$ (the moving value as a percentage of the spread).

Table 2. The spread dynamic

\begin{tabular}{|c|c|c|}
\hline & Displacement & Probability \\
\hline The price changes limit & $(1-\partial)$ & $\Pi$ \\
\hline The price remains on the same limit & $\partial \mathrm{S}$ & $(1-\Pi)$ \\
\hline
\end{tabular}

\subsection{Stoll Model Overview}

The method that resorts Stoll (1989) is a method for a spread implicit estimating, and it does determine the weight of the three components costs within the spread. Stoll model is based on the following assumptions:

* The market is informationally efficient in the sense that the variation of anticipated price of 
each asset is independent of the current and past information.

* The spread $\mathrm{S}$ is constant over the entire sample period.

* All transactions are done at the highest bid and lowest ask available on the market.

\subsection{Data and Empirical Procedures}

\subsubsection{Data}

Our empirical study is based on a database relating to listed transactions continuously to the Tunis stock market over a period stretching from January 2005 until January 2012. These data include for each action:

* Prices of transactions $\mathrm{P}_{\mathrm{T}}$ : the daily closing price.

* Securities' quoted Prices: The best offered prices Ask and the best requested prices Bid. We will focus the interest in this study on the daily values of selected assets. This choice is justified by the selection of the most active and dynamic firms on Tunis Stock Market.

\subsubsection{Methodology}

The covariance's estimation is made from closing individual data in time series over the mentioned period. In a first step, were estimated the covariances of price transaction variations, the covariances of better upper limits variations and then the covariances of the variations of the better lower limits. In a second stage, a cross section regression between the variations in price and the spread squared, permits to estimate the coefficients $\mathrm{p}_{0}$ and $\mathrm{p}_{1}$ of the following relationship:

$$
\operatorname{Cov}_{\mathrm{PT}}=\operatorname{Cov}\left(\Delta \mathrm{p}_{\mathrm{t}}, \Delta \mathrm{p}_{\mathrm{t}+1}\right)=\mathrm{p}_{0}+\mathrm{p}_{1} * \mathrm{~S}^{2}
$$

Similarly, the series of best lower limits (bid) are used to estimate the coefficients $b_{0}$ and $b_{1}$ of the following relationship :

$$
\operatorname{Cov}_{\mathrm{B}}=\operatorname{Cov}\left(\Delta \mathrm{B}_{\mathrm{t}}, \Delta \mathrm{B}_{\mathrm{t}+1}\right)=\mathrm{b}_{0}+\mathrm{b}_{1} * \mathrm{~S}^{2}
$$

A third regression from the series better of upper limits (ask) to estimate the coefficient $\mathrm{a}_{0}$ and $a_{1}$ of the following relationship:

$$
\operatorname{Cov} \mathrm{A}=\operatorname{Cov}\left(\Delta \mathrm{A}_{\mathrm{t}}, \Delta \mathrm{A}_{\mathrm{t}+1}\right)=\mathrm{a}_{0}+\mathrm{a}_{1} * \mathrm{~S}^{2}
$$

Regarding the efficiency assumption, the estimated value of three regressions constants $\left(\mathrm{P}_{0}\right.$, $\mathrm{b}_{0}$ and $\mathrm{a}_{0}$ ) should be zero. Using the same approach adopted by Stoll (1989), it is noted that the above equations can be written as follows:

$$
\begin{gathered}
\operatorname{Cov}_{\mathrm{PT}}=\operatorname{Cov}\left(\Delta \mathrm{p}_{\mathrm{t}}, \Delta \mathrm{p}_{\mathrm{t}+1}\right)=\mathrm{p}_{0}+\mathrm{p}_{1} * \mathrm{~S}^{2}=\alpha_{0}+\alpha_{1} \mathrm{~S}^{2} \\
\operatorname{Cov}_{\mathrm{PC}}=\operatorname{Cov}_{\mathrm{B}}=\operatorname{Cov} \mathrm{A}=\mathrm{b}_{0}+\mathrm{b}_{1} * \mathrm{~S}^{2}=\mathrm{a}_{0}+\mathrm{a}_{1} * \mathrm{~S}^{2}=\mathrm{B}_{0}+\mathrm{B}_{1} * \mathrm{~S}^{2}+\mathrm{v} \\
\text { Hence } \operatorname{Cov} \mathrm{PT}=\alpha_{0}+\alpha_{1} \mathrm{~S}^{2}+\mu \\
\operatorname{Cov}_{\mathrm{PC}}=\mathrm{B}_{0}+\mathrm{B}_{1} * \mathrm{~S}^{2}+\mathrm{v}
\end{gathered}
$$


Where $\mu$ and $\mathrm{v}$ are random errors; $\mathrm{S}^{2}$ the independent variable which is the spread squared, but as we have seen previously:

$$
\begin{gathered}
\operatorname{Cov}_{\mathrm{PT}}=S^{2}\left[\partial^{2}(1-2 \Pi)-\Pi^{2}(1-2 \partial)\right]=\alpha_{0}+\alpha_{1} S^{2}+\mu \\
\operatorname{Cov}_{\mathrm{PC}}=S^{2} \partial^{2}(1-2 \Pi)=\beta_{0}+\beta_{1} S^{2}+\mathrm{v} \\
\text { Hence we have: } \operatorname{Cov}_{\mathrm{PT}}=\alpha_{0}+\alpha_{1} S^{2}+\mu \\
\operatorname{Cov} \mathrm{PC}=\beta_{0}+\beta_{1} S^{2}+\mathrm{v}=S^{2} \partial^{2}(1-2 \Pi)
\end{gathered}
$$

As already mentioned above, under the efficient market hypothesis, we should have $\alpha 0+\beta 0=0$. Accordingly, the coefficients $\alpha$ land $\beta 1$ of the explanatory variable $S 2$ are determined as follows: $\quad \alpha 1=\partial 2(1-2 \Pi)-\Pi 2(1-2 \partial) \beta 1=\partial(1-2 \Pi)$

\section{Results}

Referring to the table of serial correlations, we have the following

Table 3. Serial Correlations

\begin{tabular}{|l|l|l|l|}
\hline Model & Spread & Cov $_{\mathrm{PT}}$ & Cov $_{\mathrm{PC}}$ \\
\hline Processing costs & $2\left(\prod-\partial\right) \mathrm{S}=\mathrm{S}$ & $-0,25 \mathrm{~S}^{2}$ & 0 \\
\hline Incentive costs & $0<2\left(\prod-\partial\right) \mathrm{S}=0$ & $-0,25 \mathrm{~S}^{2}<<0$ & $-0,25 \mathrm{~S}^{2}<<0$ \\
\hline Insider presence costs & $2\left(\prod^{-} \partial\right) \mathrm{S}=\mathrm{S}$ & 0 & 0 \\
\hline
\end{tabular}

We note that all spread theories do imply that covariances calculated from the transaction price should be a negative function of the spread squared. Theoretically, the coefficient should be negative for all regressions, but empirically nothing is guaranteed. Thus, our estimates show that this result is verified in transactional regressions only for two coefficients (BTEI and UBCI) among the proposed sample.

Table 4. Recapitulation of the estimation results

\begin{tabular}{|c|c|c|c|c|c|r|r|}
\hline Variables Assets & $\alpha 1$ & $\beta 1$ & $\Pi$ & $\partial$ & \multicolumn{2}{|c|}{ Proportion des composants coûts } \\
\hline & & & & & $\begin{array}{r}\text { Inventoty } \\
\text { costs }\end{array}$ & $\begin{array}{r}\text { Processing } \\
\text { costs }\end{array}$ & $\begin{array}{r}\text { Asymmetric } \\
\text { costs }\end{array}$ \\
\hline BIAT & 0,23 & $-0,01$ & 0,57 & 0,267 & $14 \%$ & $39,4 \%$ & $46,6 \%$ \\
\hline BH & 0,167 & 0,007 & 0,51 & 0,341 & $2 \%$ & $31,8 \%$ & $66,2 \%$ \\
\hline TUNIS AIR & 0,05 & 0,015 & 0,064 & 0,237 & $19,4 \%$ & $28 \%$ & $52,6 \%$ \\
\hline BTEI & $-0,15$ & 0,008 & 0,53 & 0,365 & $6 \%$ & $27 \%$ & $67 \%$ \\
\hline UBCI & 0,13 & 0,029 & 0,52 & 0,222 & $4 \%$ & $40,4 \%$ & $55,6 \%$ \\
\hline
\end{tabular}

*The covariances regression constants $\left(\alpha_{0}\right.$ and $\left.\beta_{0}\right)$

In an efficient market, the only source of serial covariance should be the spread and not the arrival of external news on the market, which implies that the constant must be zero. However, our estimates showed significantly constants different of zero as case of BIAT:

$\alpha_{0}=\mathrm{P}_{0}=-0,015 ;$ 
$\beta_{0}=a_{0}=0.0104$ for the ask price,

$\beta_{0}=b_{0}=-0.0123$ for the bid price.

The fact that the constants are different from zero does not correspond to the condition imposed by the Efficient Market Hypothesis. We consider consequently that the Tunis stock market is not informationally efficient, and that the serial covariance source should not be only the spread but also the arrival of new informations on the market. The majority of the constants of all samples were negative, which reflects that the actual sizes of current transactions exceed the implicit transaction size in the quoted spread, or even market inefficiencies. The following table contains the different results we have mention above:

$$
\begin{gathered}
\operatorname{Cov}_{\mathrm{PT}}=S^{2}\left[\partial^{2}\left(1-2 \prod\right)-\prod^{2}(1-2 \partial)\right]=\alpha_{0}+\quad \alpha_{1} S^{2}+\mu \\
\operatorname{Covp}_{\mathrm{C}}=S^{2} \partial^{2}\left(1-2 \prod\right)=\beta_{0}+\beta_{1} S^{2}+\mathrm{v}
\end{gathered}
$$

\begin{tabular}{|c|c|c|c|c|}
\hline $\begin{array}{r}\text { Endogeneous } \\
\text { Variables } \\
\end{array}$ & Constant $(\mathrm{t})$ & Coefficient of $S^{2}(t)$ & $\mathrm{R}^{2}$ & Adjusted $\mathrm{R}^{2}$ \\
\hline \multicolumn{5}{|c|}{ BIAT } \\
\hline COV PT & $\begin{array}{l}-0,015 \\
(-0,67)\end{array}$ & $\begin{array}{c}-0,75 \\
(-13,8)\end{array}$ & $47,48 \%$ & $47,28 \%$ \\
\hline COV A & $\begin{array}{l}-0,010 \\
(-0,03)\end{array}$ & $\begin{array}{l}-1,025 \\
(-15,9) \\
\end{array}$ & $51,25 \%$ & $51 \%$ \\
\hline COV B & $\begin{array}{l}-0,012 \\
(-0,41)\end{array}$ & $\begin{array}{l}-1,013 \\
(-15,75) \\
\end{array}$ & $50,54 \%$ & $50,33 \%$ \\
\hline \multicolumn{5}{|c|}{ BH } \\
\hline COV PT & $\begin{array}{c}-0,0096 \\
(-0,63) \\
\end{array}$ & $\begin{array}{l}-0,724 \\
(-15,8) \\
\end{array}$ & $46,33 \%$ & $46,14 \%$ \\
\hline CDV A & $\begin{array}{l}-0,054 \\
(-1,03) \\
\end{array}$ & $\begin{array}{c}-1,333 \\
(-22,05) \\
\end{array}$ & $66,68 \%$ & $66,55 \%$ \\
\hline COV B & $\begin{array}{l}-0,043 \\
(-1,45) \\
\end{array}$ & $\begin{array}{c}-1,013 \\
(-17,46) \\
\end{array}$ & $55,67 \%$ & $55,5 \%$ \\
\hline \multicolumn{5}{|c|}{ BTEI } \\
\hline CDV PT & $-0,0010(-0,100)$ & $\begin{array}{c}-416,2 \\
(-21,76) \\
\end{array}$ & $58,08 \%$ & $57,95 \%$ \\
\hline COV A & $\begin{array}{c}-0,0031 \\
(-0,19) \\
\end{array}$ & $\begin{array}{l}-1,230 \\
(-19,7) \\
\end{array}$ & $61,5 \%$ & $61,3 \%$ \\
\hline COV B & $\begin{array}{l}-0,0032 \\
(-0,237) \\
\end{array}$ & $\begin{array}{c}-1,092 \\
(-17,20) \\
\end{array}$ & $54,62 \%$ & $54,44 \%$ \\
\hline \multicolumn{5}{|c|}{ Tunis air } \\
\hline COV PT & $\begin{array}{c}0,018 \\
(1,094) \\
\end{array}$ & $\begin{array}{c}-0,833 \\
(-15,60) \\
\end{array}$ & $41,66 \%$ & $41,5 \%$ \\
\hline COV A & $\begin{array}{c}-0,021 \\
(-0,923) \\
\end{array}$ & $\begin{array}{l}-0,888 \\
(-13,9) \\
\end{array}$ & $44,40 \%$ & $44,17 \%$ \\
\hline COV B & $\begin{array}{l}-0,021 \\
(-0,89) \\
\end{array}$ & $\begin{array}{c}-0,903 \\
(-14,14)\end{array}$ & $45,15 \%$ & $45 \%$ \\
\hline \multicolumn{5}{|c|}{ UBCI } \\
\hline COV PT & $\begin{array}{c}0,058 \\
(-1,84)\end{array}$ & $\begin{array}{l}-1,180 \\
(-19,86)\end{array}$ & $59 \%$ & $58,9 \%$ \\
\hline COV A & $\begin{array}{c}-0,043 \\
(-0,980)\end{array}$ & $\begin{array}{c}-1,10 \\
(-17,26)\end{array}$ & $55 \%$ & $54,9 \%$ \\
\hline
\end{tabular}

Table 5. Recapitulation of the main regressions' results 


\begin{tabular}{|c|c|c|c|c|}
\hline COV B & $\begin{array}{c}-0,048 \\
(-1,06)\end{array}$ & $\begin{array}{c}-1,113 \\
(-17,82)\end{array}$ & $56,65 \%$ & $56,47 \%$ \\
\hline
\end{tabular}

\section{Interpretation}

Tableau 6. The average components of the spread costs

\begin{tabular}{|c|c|}
\hline Costs' components of quoted spread & Proportion \\
\hline Inventory costs & $10,8 \%$ \\
\hline Processing costs & $42,72 \%$ \\
\hline Asymmetric information costs & $46,48 \%$ \\
\hline Total quoted spread & $100 \% \mathrm{~S}$ \\
\hline
\end{tabular}

The table above reflects an econometric measure of liquidity via the bid-ask spread quoted by the market maker. This latter is regarded as a liquidity producer, setting purchase and sale prices which reflect consequently his costs. Accordingly, a financial intermediate, by adjusting his prices to his inventory (avoid extreme positions), increases or decreases his commissions. Therefore, he does maintain such a gap in terms of his risk aversion. In our case, the inventory holding cost is around $10.8 \%$, which is relatively weak compared to the theoretical investigations in this area. This finding may draw its essence from the fact that transacted assets on the Tunis stock market are relatively sparsely active, and the market is sluggish. In its turn, asymmetric information cost represents the dominant component in the market maker spread formation with a proportion of about $50 \%$ of informational transactions, proof that this stock market appears somewhat sensitive to any information concerning particularly companies (capital increase rumors, dividend distribution, reserves incorporation ....) and the whole Tunisian economy (political and social stability, financial law, international financial dependency ...). Moreover, the processing costs constitute such an important spread morsel, about (42\%), which can be explained by the fact that orders' splitting or the practice of hidden orders may generate gradual adjustments of prices quoted by the market maker. In addition, it also appears that these costs can be a reflection of investors' behavior whose transacting reasons are other than those informational. By intervening in the market, these investors qualified as "liquidity traders" do camouflage the informed and the price system is consequently noisy. In short, the market maker regarded as a permanent market liquidity supplier, has to incorporate into his quoted prices some costs that pay the immediacy service, such costs are undergone by market investors

\section{Conclusion}

The purpose of this study was to explain and test empirically liquidity measuring. We proceeded first to analyze financial market microstructure as the general framework of these markets' liquidity. Then, we examined theoretically the relation tying liquidity and market structure. And eventually, the interest is focused on liquidity measuring methods. The last stage of this work was dedicated for the empirical investigation involving a measure of liquidity via bid-ask spread. By resorting to Stoll Model methodology (1989) on the covariance s' regressions, the results we have reached support a finding that the component costs of the measured spread via daily data on the Tunis stock market are significantly important, showing that this market is not sufficiently liquid and consequently not very 
dynamic (amply wide spread, synonym of a small market). In brief, the success and failure of such a stock market are dictated by of its liquidity state.

\section{References}

Admati, A., \& Pfleiderer, P. (1988). A theory of intraday pattern: volume and price variability. Review of Financial Studies, 1(1), 3- 40. http://dx.doi.org/10.1093/rfs/1.1.3

Ai, H. (2010). Information quality and long-run risk: asset pricing implications. Journal of Finance, 65(4), 1333-1368. http://dx.doi: 10.1111/j.1540-6261.2010.01572.

Amihud, Y., \& Mendelson, H. (1986). Liquidity and stock returns. Financial Analysts Journal, 42, 43-48. http://dx.doi.org/10.2469/faj.v42.n3.43

Biais, B. (1993). Price formation and equilibrium in fragmented and centralized $\begin{array}{llll}\text { markets. } & \text { Journal } & \text { Finance, } & 48(1),\end{array}$ http://dx.doi.org/10.1111/j.1540-6261.1993.tb04705.x

Biais, B., Hillion, P., \& Spatt, C. (1995). An empirical analysis of the limit order book and the order flowing the Paris Bourse. Journal of Finance, 50(5), 1655-1689. http://dx.doi.10.1111/j.1540-6261.1995.tb05192.x

Bikhchandani, B., Hirschleifer, D., \& Welch, I. (1992). A theory of fads, faction, custom and cultural changes as informational cascades. Journal of Political Economy, 100(3), 92-1026. http://dx.doi.org/10.1086/261849

Brockman, P., \& Chung, D. Y. (2000). An empirical investigation of trading asymmetric information and heterogeneous prior beliefs. Journal of Empirical Finance, 7(5), 417-454. http://dx.doi.org/10.1016/S0927-5398(00)00020-7

Chordia, T., \& Swaminathan, L. (2000). Trading volume and Cross autocorrelation in stock returns. Journal of Finance, 55(2), 913-935 http://dx.doi.org/10.1111/0022-1082.00231

Copeland T. E., \& Galai, D. (1983). Information effects of the bid - ask spread. Journal of Finance, 38(5), 1457-1469. http://dx.doi.org/10.1111/j.1540-6261.1983.tb03834.x

Easley, D., \& O'Hara, M. (2010). Microstructure and ambiguity. Journal of Finance, 65(5), 1817-1846. http://dx.doi.org/10.1111/j.1540-6261.2010.01595.x

Easley, D., \& O'Hara, M. (1987). Price, trade size and information in securities markets. Journal of Financial Economics, 19, 69-90. http://dx.doi.org/10.1016/0304-405X(87)90029-8

Easley, D., Hvidkjar, S., \& O'Hara, M. (2002). Is information risk a determinant of asset returns? Journal of Finance, 57, 2185-2222. http://dx.doi.org/10.1111/1540-6261.00493

Foucault, T. (1999). Order flow composition and trading casts in a dynamic limit order $\begin{array}{lllll}\text { market. Journal of } & \text { Financial } & \text { Markets, } & 2, & 99-134 .\end{array}$ http://dx.doi.org/10.1016/S1386-4181(98)00012-3

Garman, M. (1976). Market microstructure. Journal of financial Economics, 3, 257-275. 


\section{Macrothink}

Business and Economic Research ISSN 2162-4860 2016, Vol. 6, No. 2

Grossman, S., \& Miller, M. (1989). Liquidity and market structure. Journal of Finance, 42, 617-637.

Glosten, L. R., \& Milgrom, P. R. (1985). Bid, ask and transaction prices in a specialist market with heterogeneously informed traders. Journal of Financial Economics, 14, 71-100. http://dx.doi.org/10.1016/0304-405X(85)90044-3

Hailer, A., \& Stoll, H. R. (1989). Market structure and transaction Costs, implied spreads in the German stock market. Journal of Banking and Finance, 13, 697-708. http://dx.doi.org/10.1016/0378-4266(89)90038-1

Hirschey, M. (2001). Investments: Theory and applications. Harcourt college publishers.

Ho, T. S., \& Stoll, H. R. (1983). The dynamics of dealer markets under competition. Journal of Finance, 38, 1053-1074. http://dx.doi.org/10.1111/j.1540-6261.1983.tb02282.x

Hu, G. X., Pan, J., \& Wang, J. (2013). Noise as information for illiquidity. Journal of Finance, 68, 2341-2382. http://dx.doi.org/10.1111/jofi.12083

Jennings, R. (1998). Order flow distribution, Bid-Ask spreads and liquidity costs. Journal of financial intermediation, 3, 358-385. http://dx.doi.org/10.1006/jfin.1998.0247

Karpoff, J. M. (1986). A theory of trading volume. Journal of financial Economics and quantitative analysis, 22, 108-126. http://dx.doi.org/10.2307/2328164

Kyle, A. (1985). Continuous auction and insider trading. Economica, 53, 1315-1335. http://dx.doi.org/10.2307/1913210

Lee, Y.T., Lin, J.C., \& Liu, Y.J. (1999). Trading patterns of big versus small players in an emerging market. Journal of Banking and Finance, 23(5), 701-726 http://dx.doi.org/10.1016/S0378-4266(98)00116-2

Leland, H. (1992). Insider trading. Journal of Political Economic, 100(4), 859-887. http://dx.doi.org/10.1086/261843

Roll, R. (1984). A simple implicit measure of the effective bid-ask spread in an efficient Market. Journal of Finance, 39, 1127-1139. http://dx.doi.org/10.1111/j.1540-6261.1981.tb04890.x

Shiller, R. J. (1999). Measuring bubble expectations and investor confidence. Journal of finance, Working paper 7008. http://dx.doi.org/10.1086/261843

Stoll, H. (1989). Inferring the components of the bid ask spread: Theory and empirical tests, Journal of Finance, 44, 115-125. http://dx.doi.org/10.1111/j.1540-6261.1989.tb02407.x

Zhang, X. F. (2006).Information uncertainty and stock returns. Journal of finance, 61, 105-139. http://dx.doi.org/10.1111/j.1540-6261.2006.00831.x

Ziegler, A. (2001) .Optimal portfolio choice under heterogeneous beliefs. European Finance Review, 4, 45-59. http://dx.doi.org/10.1111/j.1540-6261.2006.00831.x 


\section{Copyright Disclaimer}

Copyright for this article is retained by the author(s), with first publication rights granted to the journal.

This is an open-access article distributed under the terms and conditions of the Creative Commons Attribution license (http://creativecommons.org/licenses/by/3.0/). 